\title{
Analisis Status Gizi, Tingkat Kecemasan, Umur, Dan Kadar Gula Darah Dengan Kualitas Hidup Pasien Dm Tipe 2
}

\author{
Agnes Anastasya Rihi Leo ${ }^{1 *}$, Rosalia Valentina Kedo ${ }^{2}$ \\ ${ }^{1}$ UPTD Puskesmas Manutapen, Dinas Kesehatan Kota Kupang, Indonesia. \\ ${ }^{2}$ Program Studi S1 Ilmu Gizi, Sekolah Tinggi Ilmu Kesehatan Nusantara Kupang; Instalasi Gizi RSB. \\ Titus Ully Kupang \\ e-mail: ${ }^{1 *} \underline{\text { nes_rihileo@yahoo.co.id }}$
}

\begin{abstract}
ABSTRAK
Diabetes Melitus (DM) adalah salah satu kelompok penyakit metabolik yang ditandai dengan kadar gula darah melebihi normal karena kelainan sekresi insulin atau kerja insulin atau keduanya. Penelitian ini merupakan penelitian kuantitatif dengan desain penelitian korelasi menggunakan rancangan penelitian cross-sectional. Sampel yang diambil adalah pasien yang datang kemudian dirawat inap dan rawat jalan di RS Bhayangkara pada bulan Januari - Februari 2019 yaitu sebanyak 30 orang. Data yang diperoleh akan dianalisis dengan komputerisasi menggunakan program SPSS. Hasil penelitian menunjukanan ada hubungan status gizi dengan kualitas hidup pasien DM ( $\mathrm{p}=0,03 ; \mathrm{r}=0,4)$, ada hubungan kadar glukosa darah dengan kualitas hidup pasien DM ( $\mathrm{p}=0.002$; $\mathrm{r}=-0,55)$, tidak ada hubungan antara umur dengan kualitas hidup pasien DM ( $\mathrm{p}=0,17$; $\mathrm{r}=-0,63)$, serta tidak ada hubungan antara tingkat kecemasan dengan kualitas hidup pasien DM ( $\mathrm{p}=0,33)$. Kesimpulan pada penelitian ini yaitu ada hubungan antara glukosa darah dan status gizi dengan skor kualitas hidup pasien DM.
\end{abstract}

Kata kunci: Status Gizi, Tingkat Kecemasan, Kadar Gula Darah, Umur.

\begin{abstract}
Diabetes Mellitus (DM) is one of a group of metabolic diseases characterized by blood sugar levels exceeding normal due to abnormalities of insulin secretion or insulin work or both. This research is quantitative research with correlation research design using cross-sectional research design. The samples taken were patients who came and were hospitalized and outpatient at Bhayangkara Hospital in January - February 2019, which was 30 people. The data obtained will be analyzed by computerization using SPSS program. The results showed that there is a relationship of nutritional status with the quality of life of DM patients $(p=0.03 ; r=0,4)$, there is a relationship between blood glucose levels and the quality of life of DM patients ( $p=0.002 ; r=-0.55)$, there is no relationship between age and dm patient quality of life $(p=0.17$; $r=-0.63)$, and there is no association between anxiety levels and dm patient quality of life $(p=0.33)$. The conclusion of this study is that there is a link between blood glucose and nutritional status with dm patient quality of life score.
\end{abstract}

Keywords: Nutritional Status; Anxiety Levels; Nutritional Status; Blood Sugar Levels; age

\section{PENDAHULUAN}

Diabetes Melitus (DM) tipe II merupakan salah satu gangguan metabolik yang ditandai dengan kadar glukosa darah (gula darah) melebihi normal yaitu kadar gula darah sewaktu $\geq 200$ $\mathrm{mg} / \mathrm{dL}$, dan kadar gula darah puasa $\geq 126 \mathrm{mg} / \mathrm{dL}[1]$. DM tipe II umumnya disebabkan oleh faktor pertambahan usia, oleh karena itu DM tidak bisa disembuhkan namun dapat dikendalikan dengan cara menjaga kesehatan tubuh dengan pola hidup sehat dan mengendalikan serta mengontrol kadar gula darah dalam batasan normal[2].

Indonesia menduduki urutan ketujuh di dunia kasus DM pada rentang usia 20-79 tahun di tahun 2013 serta diproyeksikan tetap masuk dalam sepuluh besar negara dengan prevalensi DM tertinggi di dunia sampai tahun 2030. Pada tahun 2013, prevalensi DM di Indonesia mengalami peningkatan dibandingkan dengan tahun 2007 sebanyak 1,2\% menjadi 6,9\%. Provinsi Nusa Tenggara Timur merupakan Provinsi dengan prevalensi DM kedua tertinggi di Indonesia yaitu sebesar 3,3\% dan terendah di Provinsi lampung sebesar 0,8\%. DM tipe II juga sebagai salah satu 
penyebab utama kematian dengan persentase yang disebabkan oleh penyakit lain sekitar $2,1 \%$. Panjang usia seseorang dipengaruhi oleh kualitas hidup yang tinggi dan faktanya pasien membutuhkan hidup yang berkualitas untuk terus menjalankan hidupnya[3].

Diantara semua penderita diabetes, meskipun tersedia pengobatan yang efektif kebanyakan dari mereka sulit untuk mengendalikan kadar glukosa darahnya sehingga muncul komplikasi dan berisiko mengurangi kualitas hidup pasien tersebut[4]. Penelitian ini bertujuan untuk menganalisis hubungan umur, status gizi, kadar glukosa darah, dan skor kecemasan dengan kualitas hidup pasien DM tipe 2 di RSB Titus Uly Kupang.

\section{BAHAN DAN METODE}

Penelitian ini merupakan penelitian kuantitatif dengan rancangan cross-sectional. Penelitian ini dilakukan di Rumah Sakit Bhayangkara Kupang pada bulan Januari - Februari 2019. Populasi dalam penelitian ini adalah seluruh pasien DM rawat jalan maupun rawat inap di RSB Titus Uly Kupang pada Bulan Februari sampai Maret 2019 yaitu berjumlah 30 orang. Teknik pengambilan sampel menggunakan teknik total sampling sehingga jumlah sampel yang digunakan sejumlah 30 sampel.

Variabel terikat dalam penelitian ini adalah kualitas hidup pasien DM sedangkan variable bebas dalam penelitian ini antara lain umur, tingkat kecemasan, kadar gluosa darah dan status gizi pasien DM rawat Inap dan rawat jalan. Kualitas hidup pasien diukur dengan menggunakan kuisioner Kualitas hidup yang diadaptasi dari kuisioner World Health Organization HO Quality of life (WHOQOL) dengan satuan persen (\%), kadar glukosa darah diukur dengan menggunakan glukometer, skor kecemasan diukur dengan menggunakan kuisioner DASS (Then Depression Anxiety Stress Scale) dengan kategori kecemasan berat jika $>2$ dan ringan jika $\leq 2$, sedangkan status gizi diukur dengan menggunakan IMT dengan kategori Malnutrisi jika IMT $<18$ dan $>25$ dan Normal jika IMT 18 - 25[5].

Data dikumpulkan dan dianalisis secara univariat dan bivariat. Analisis univariat untuk variable status gizi dan tingkat kecemasan menggunakan table distribusi frekuensi sedangkan variabel umur dan kadar glukosa darah menggunakan nilai median (min-max). Analisis bivariat untuk melihat hubungan antara variabel bebas dan variabel terikat dengan menggunakan uji rank spearman untuk variabel bebas numeric (kadar gula darah dan umur dengan kualitas hidup) Sedangkan untuk variabel bebas kategorik (tingkat kecemasan dan status gizi dengan kualitas hidup) menggunakan Mann Whitney dengan tingkat kemaknaan 0,05.

\section{HASIL DAN PEMBAHASAN}

\section{Gambaran Karekteristik Responden}

Gambaran karakteristik responden penelitian meliputi jenis kelamin, status gizi dan tingkat kecemasan. Gambaran karakteristik responden ditujukan untuk mengetahui sebaran responden berdasarkan jenis kelamin, status gizi dan tingkat kecemasan. Gambaran karakteristik responden dapat dilihat pada tabel 1 .

Tabel 1. Gambaran Karakteristik Responden Berdasarkan Jenis Kelamin, Status Gizi, dan Tingkat Kecemasan Pasien DM Tipe 2

\begin{tabular}{lcc}
\hline \multicolumn{1}{c}{ Variabel } & n & \% \\
\hline Jenis Kelamin & & \\
Laki-laki & 13 & 43,3 \\
Perempuan & 17 & 56,7 \\
\hline Status Gizi & & \\
Malnutrisi & 13 & 43,3 \\
Normal & 17 & 56,7 \\
\hline Tingkat kecemasan & & \\
Berat & 12 & 40
\end{tabular}




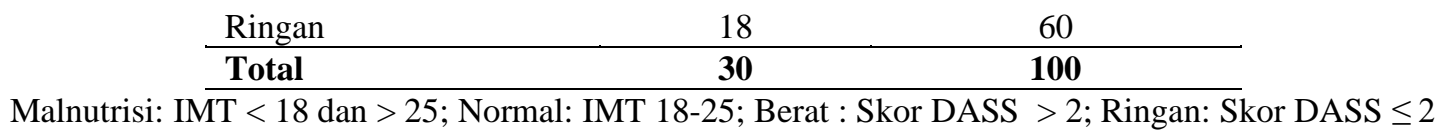

Tabel 1 menunjukan sebagian besar responden berjenis kelamin perempuan $(56,7 \%)$, status gizi normal $(56,7 \%)$ dan memiliki tingkat kecemasan ringan $(60 \%)$.

Tabel 2. Deskripsi Umur, Kadar Gula Darah dan Kualitas Hidup Pasien DM Tipe 2

\begin{tabular}{lcc}
\hline \multicolumn{1}{c}{ Variabel } & Mean & Min-Max \\
\hline Umur (tahun) & 60 & $37-80$ \\
Kadar Gula Darah (mg/dL) & 201 & $108-485$ \\
Kualitas Hidup (\%) & 69,5 & $55-78$ \\
\hline
\end{tabular}

Tabel 2 menunjukan nilai tengah untuk umur responden adalah 60 tahun dengan umur termuda 37 tahun dan tertua adalah 80 tahun. Nilai tengah untuk kadar gula darah adalah 201 $\mathrm{mg} / \mathrm{dL}$ dengan kadar terendah $108 \mathrm{mg} / \mathrm{dL}$ dan tertinggi $485 \mathrm{mg} / \mathrm{dL}$ dan nilai tengah dari persen kualitas hidup responden adalah 69,5\% dengan kualitas hidup terendah 55\% dan kualitas hidup tertinggi $78 \%$.

\section{Analisis Faktor Risiko}

Tabel 3. Analisis Faktor Risiko Kualitas Hidup

\begin{tabular}{lc}
\hline \multicolumn{1}{c}{ Faktor Risiko } & $\mathbf{p}$ \\
\hline Jenis Kelamin & $0,65^{\mathrm{a}}$ \\
Status Gizi & $0,02^{\mathrm{a}}$ \\
Tingkat Kecemasan & $0,33^{\mathrm{a}}$ \\
Umur & $0,21(\mathrm{r}=-0,24)^{\mathrm{b}}$ \\
Kadar Gula Darah & $0,002(\mathrm{r}=-0,54)^{\mathrm{b}}$ \\
\hline \multicolumn{1}{c}{${ }^{\mathrm{a}}$ Uji Mann Whitney } & ${ }^{\mathrm{b}} \mathrm{Uji}$ Spearman
\end{tabular}

Tabel 3 menunjukkan ada hubungan antara status gizi dengan kualitas hidup pasien DM tipe 2 rawat inap dan rawat jalan pada RSB Titus Ully Kupang $(\mathrm{p}=0,02)$, dan tidak ada hubungan antara tingkat kecemasan dengan kualitas hidup pasien DM tipe $2(\mathrm{p}=0,33)$. Hasil analisis dengan Uji Spearman menunjukan tidak ada hubungan antara umur dengan kualitas hidup pasien DM tipe $2(p=0,21)$ dengan arah korelasi negatif $(-0,24)$ yang berarti semakin bertambah umur maka kualitas hidup pasien DM semakin menurun. Hasil analisis menunjukan ada hubungan antara kadar gula darah dengan kualitas hidup pasien DM $(\mathrm{p}=0,002)$ dengan arah korelasi negatif $(-0,54)$ yang berarti semakin tinggi kadar gula darah pasien DM tipe 2 maka semakin rendah kualitas hidup pasien.

Menurut World Health Organization Quality of Life (WHOQOL) Group Kualitas hidup merupakan penilaian sesorang akan kehidupannya dirinya sendiri dalam pandangan kultur/budaya dan sistem nilai di lingkungan hidupnya dan korelasinya dengan tujuan, harapan, standar yang ditetapkan dan perhatian seseorang[6,7]. Penelitian yang dilakukan di Rumah Sakit Bayangkara menunjukan adanya hubungan antara status gizi dengan kualitas hidup pasien DM. Status gizi merupakan kondisi atau keadaan seseorang akibat mengkonsumsi zat gizi dari makanan. Masalah gizi bukan hanya disebabkan oleh asupan makanan saja melainkan juga karena adanya penyakit/infeksi. Apabila sesorang memperoleh makanan namun memiliki penyakit/infeksi maka status gizinya akan terganggu. Terdapat hubungan yang signifikan antara penyakit infeksi seperti diare dengan status gizi pada batita [8]. Hasil penelitian ini sejalan dengan penelitian yang dilakukan pada Pegawai Negeri Sipil di Kantor Sekda Kabupaten Sinjai menunjukan ada hubungan status gizi yang diukur melalui indeks massa tubuh dan lingkar pinggang dengan kadar gula darah sewaktu $(\mathrm{p}=0,017)$ [9]. 
Responden dalam penelitian ini kebanyakan lanjut usia, dimana selain penyakit DM responden yang lanjut usia rentan terhadap penyakit lainnya seperti hipertensi. Terdapat hubungan yang signifikan antara asupan zat gizi dengan hipertensi. [10] Kegemukan/obesitas dapat memicu intoleransi glukosa. Asam lemak bebas pada individu yang mengalami obesitas memiliki efek yang berlawanan dengan insulin sehingga menyebabkan penurunan sensitivitas insulin karena tubuh seseorang menjadi gemuk lantaran terjadi penimbunan lemak atau sebaliknya [11]. Kegemukan merupakan faktor pendorong hiperglikemi, disebabkan karena penurunan sensivitas pada sel-sel pulau langerhans terhadap kenaikan gula darah sehingga menyebabkan resistensi reseptor insulin pada sel-sel di seluruh tubuh [12]. Pada penderita obesitas terjadi penurunan kadar adinopektin. Adinopektin merupakan hormone yang dapat meningkatkan sensivitas insulin. Selain itu, asam lemak yang dikelurkan pada penderita obes mengganggu sekresi insulin di otot. Pengendalian berat badan pada pasien obes diyakini dapat membantu memperbaiki kadar glukosa darah jangka pendek dan mempunyai potensi meningkatkan kontrol metabolik jangka lama [13]. Oleh karena itu, pasien DM tipe 2 yang mengalami obesitas berisiko mengalami komplikasi yang dapat menurunkan kualitas hidup pasien DM dan meingkatkan risiko kematian.

Penelitian ini menunjukan tidak ada hubungan antara skor kecemasan dengan kualitas hidup pasien DM. Hasil analisis menunjukan arah korelasi negatif yang berarti semakin cemas maka semakin rendah kualitas hidup pasien DM. Efek membangun maupun destruktif dapat ditimbulkan dari kecemasan. Efek membangun timbul jika menimbulkan dorongan positif pada diri individu untuk menghilangkan ketidaknyamanan yang dialaminya demi kelangsungan hidupnya, sedangkan efek destruktif terjadi jika individu bertingkah laku meladaptif dan disfungsional [14]. Beban secara psikis akan timbul pada diri penderita diabetes maupun dalam keluarga. Beban psikologis yang terjadi dapat menyebabkan efek yang buruk antara lain penderitaan, di mana secara signifikan dapat berakibat pada penatalaksanaan perawatan diabetes sehari-hari secara mandiri serta dikorelasikan dengan hasil medis yang buruk serta meningkatkan beban biaya perawatan sehingga menyulitkan proses penatalaksanaan perawatan pada penderita DM tipe 2. Hal ini lah yang menyebabkan menurunnya kualitas hidup pasien DM tipe 2 dan meningkatkan risiko kematian[15]. Hasil Penelitian yang dilakukan di Puskesmas Pleret Bantul menunjukan tidak ada hubungan tingkat kecemasan dengan kualitas hidup pasien DM di Puskesmas Pleret Bantul ( $\mathrm{p}=0,249)$ [16].

Penelitian menunjukan bahwa tidak ada hubungan antara umur dengan kualitas hidup pasien DM. Namun hasil analisis menunjukan arah korelasi negative yang berarti semakin tinggi umur maka kualitas hidup pasien DM tipe 2 semakin rendah. Penelitian ini sejalan dengan penelitian yang dilakukan di Kabupaten Pasuruan yang menunjukan tidak ada hubungan antara umur dengan kualitas hidup pasien DM di RSUD Bangil Kabupaten Pasuruan ( $p=0,186)$ [17]. Kualitas hidup seseorang sangat dipengaruhi oleh factor usia. Pertambahan usia mengakibatkan penurunan fungsi dan anatomi tubuh yang berimbas pada resintensi insulin serta gangguan toleransi gula darah. Oleh karena itu, masalah seperti fisik, psikis, dan sosial dapat muncul dan mengakibatkan penurunan kualitas hidup. Menurunnya kemampuan atau fungsi tubuh berpengaruh terhadap keberhasilan penatalaksanaan diabetes dan berakibat munculnya gangguan kesehatan sehingga menurunkan kualitas hidup pasien DM [18].

Penelitian ini menunjukan bahwa terdapat hubungan antara kadar glukosa darah dengan kualitas hidup pasien DM ( $\mathrm{p}=0,002)$. Hasil analisis menunjukan arah korelasi negatif yang berarti semakin tinggi kadar glukosa darah semakin rendah kualitas hidup pasien DM. P value $(\mathrm{r}=-0,55)$. Diabetes Melitus merupakan salah satu kelompok penyakit metabolik dengan cirri khas peningkatan kadar gula dalam darah karena kelainan kerja insulin atau sekresi insulin, atau keduanya. Penelitian yang dilakukan di Surakarta pada peserta Prolanis Askes menunjukan ada hubungan kadar glukosa darah dengan kualitas hidup pada pasien DM tipe $2(\mathrm{p}=0,001 ; \mathrm{r}=-0,064)$ [19]. Menurut WHO salah satu factor yang mempengaruhi kualitas hidup adalah kadar gula darah. Kadar glukosa dalam darah sangat mempengaruhi keadaan fisik seseorang. kadar gulkosa yang dialirkan melalui darah adalah sumber utama energi untuk sel-sel tubuh, dan aktivitas sehari-hari memiliki ketergantungan terhadap energi. Dengan demikian status glukosa dalam darah jelas 
sangat mempengaruhi kemampuan seseorang dalam melakukan aktivitas kesehariannya yang mana secara langsung kemampuan melaksanakan aktivitas harian akan mempengaruhi kualitas. Kalau kandungan Glukosa dalam dara tinggi berarti sel tidak bisa mengubah glukosa menjadi energi, namun untuk mengubah glukosa menjadi energi perlu bantuan dari insulin. Kalo pada DM tipe 2 ada resistensin insulin sehingga glukosa yang ada di dalam darah tidak dapat masuk dalam sel untuk menghasilkan energi, kalo glukosa tidak dapat mengubah menjadi energi maka glukosa tidak dapat melaksanakan fungsi fisik karena fisik memerlukan energi.

\section{KESIMPULAN}

Hasil Penelitian menunjukan ada hubungan antara kadar glukosa darah dan status gizi dengan kualitas hidup pasien DM ttipe 2 rawat jalan dan rawat inap di RSB. Titus Uly Kupang. Oleh karena itu, pasien DM tipe 2 dianjurkan untuk mencapai dan mempertahankan ststus gizi optimal melalui asupan makanan dan aktivitas fisik serta menjaga kadar gula darah dengan patuh mengkonsumsi obat.

\section{DAFTAR PUSTAKA}

[1] Hestiana DW. Faktor-faktor yang berhubungan dengan kepatuhan dalam pengelolaan diet pada pasien rawat jalan diabetes mellitus tipe 2 di Kota Semarang. JHE (Journal of Health Education). 2017;2(2):137-45.

[2] Tjokrokusumo D. Mencegah dan melawan penyakit kanker dan degeneratif dengan jamur kancing (Agaricus bisporus). Diabetes.;1:3.

[3] Balitbang Kemenkes RI. Riset kesehatan dasar; RISKESDAS. Jakarta: Balitbang Kemenkes RI. 2013;2013:110-9.

[4] Teli M. Kualitas Hidup Pasien Diabetes Melitus Tipe 2 Di Puskesmas Se Kota Kupang. Jurnal Info Kesehatan. 2017 Jun 30;15(1):119-34.

[5] Oktaviani WD. Hubungan kebiasaan konsumsi fast food, aktivitas fisik, pola konsumsi, karakteristik remaja dan orang tua dengan indeks massa tubuh (IMT)(studi kasus pada siswa SMA Negeri 9 Semarang tahun 2012). Jurnal Kesehatan Masyarakat Universitas Diponegoro. 2012;1(2):18843.

[6] Fitriana NA. Kualitas hidup pada penderita kanker serviks yang menjalani pengobatan radioterapi (Doctoral dissertation, Universitas Airlangga).

[7] Herdianti H. Determinan Kualitas Hidup Penderita DM Tipe 2 di RSUD Ajjappange. Jurnal Endurance: Kajian Ilmiah Problema Kesehatan. 2017 Feb 9;2(1):74-80.

[8] Purwanti DY, Ratnasari D. Hubungan Antara Kejadian Diare, Pemberian Asi Eksklusif, Dan Stunting Pada Batita. Jurnal Ilmiah Gizi dan Kesehatan (JIGK). 2020 Mar 2;1(02):1523.

[9] Achmad AF, Faradiana S, Rahmayani AM. Hubungan Status Gizi terhadap Kadar Gula Darah Sewaktu dan Tekanan Darah. Celebes Health Journal. 2019 Jun 25;1(1):40-8.

[10] Masrikhiyah R, Setyaningsih S. Hubungan Asupan Zat Gizi Dan Aktivitas Fisik Pada Lansia Dengan Kejadian Hipertensi. Jurnal Ilmiah Gizi dan Kesehatan (JIGK). 2019 Aug 29;1(01):28-33.

[11] Masruroh E. Hubungan Umur Dan Status Gizi Dengan Kadar Gula Darah Penderita Diabetes Melitus Tipe II. Jurnal Ilmu Kesehatan. 2018(6).

[12] Guyton AC, Hall JE. Buku ajar fisiologi kedokteran edisi 11. Jakarta: EGC. 2007:81-5.

[13] Sherwood L. Fisiologi Manusia dari Sel ke Sistem. EGC. Jakarta. 2020:229-31.

[14] Stuart GW. Buku saku keperawatan jiwa. edk 5. Cetakan Pertama. Jakarta: Kapoh, R, EGC. 2007.

[15] Tri Hastuti R. Faktor-faktor Risiko Ulkus Diabetika Pada Penderita Diabetes Mellitus (Studi Kasus di RSUD Dr. Moewardi Surakarta) (Doctoral dissertation, Program Pasca Sarjana Universitas Diponegoro). 
[16] Rahmat I. Hubungan Tingkat Stres dengan Kualitas Hidup pada Pasien Diabetes Melitus di Puskesmas Pleret Bantul (Doctoral dissertation, STIKES 'Aisyiyah Yogyakarta).

[17] Dwi W. Analisis Kualitas Hidup Pasien Diabetes Melitus Tipe II di RSUD Bangil Kabupaten Pasuruan. Artikel Ilmiah. 2013;1(2).

[18] Herdianti H. Determinan Kualitas Hidup Penderita DM Tipe 2 di RSUD Ajjappange. Jurnal Endurance: Kajian Ilmiah Problema Kesehatan. 2017 Feb 9;2(1):74-80.

[19] Dewi RK. Hubungan antara kadar glukosa darah penderita diabetes melitus tipe 2 dengan kualitas hidup pada peserta prolanis askes di Surakarta (Doctoral dissertation, Universitas Muhammadiyah Surakarta). 